\title{
Correlation between fertility and levels of protein, sugar and free amino acids in seminal plasma of Nelore bulls
}

[Correlação entre fertilidade e níveis de proteina, açúcar e aminoácidos livres no plasma seminal de touros Nelore]

\author{
T.I. Assumpção ${ }^{1}$, R.A.A. Torres Júnior ${ }^{2}$, M.V. Sousa ${ }^{1}$, C.A.O. Ricart ${ }^{1}$ \\ ${ }^{1}$ Departamento de Biologia Celular (IB) - Universidade de Brasília \\ Campus Universitário Darcy Ribeiro \\ 70910-900 - Brasília, DF \\ ${ }^{2}$ EMBRAPA Gado de Corte - Campo Grande, MS
}

\begin{abstract}
Correlations between fertility and the concentrations of proteins, reducing sugars and 17 types of free amino acids in the seminal plasma of Nelore bulls were estimated. The samples were collected from 19 bulls that had high quality semen, according to physical and morphological analyses. The bulls had their fertility scores estimated based on the pregnancy of the females mated to them during three consecutive breeding seasons, either by artificial insemination or by natural breeding. A large variability in the concentrations of the molecules was observed among the samples and a significant correlation coefficient $(\mathrm{r}=0.90)$ between levels of proteins and reducing sugars was estimated. None of the components showed a significant correlation with fertility.
\end{abstract}

Keywords: bull, Nelore, seminal plasma, fertility, biochemical composition

\section{RESUMO}

Estimaram-se as correlações entre fertilidade e concentrações de proteínas, açúcares redutores e 17 tipos de aminoácidos livres do plasma seminal de 19 touros Nelore, adultos, doadores de sêmen de alta qualidade segundo as análises físicas e morfológicas. O escore de fertilidade foi estimado de acordo com a porcentagem de gestação das fêmeas cobertas em três estações de monta consecutivas, por inseminação artificial ou monta natural. Foi observada alta variabilidade na concentração das moléculas analisadas nas amostras. O coeficiente de correlação estimado entre concentrações de proteina e de açúcares redutores foi de 0,90. Individualmente, nenhum dos componentes quantificados apresentou correlação significativa com a fertilidade dos touros.

Palavras-chave: touro, Nelore, plasma seminal, fertilidade, composição bioquímica

\section{INTRODUCTION}

The fertility of a bull depends on a series of factors which range from animal behavior and physical conditions to features linked directly to the semen, such as spermatozoa motility, levels of specific spermatic membrane proteins and biochemical composition of the seminal plasma
(Austin and Short, 1990). The seminal plasma is a very complex mixture of secretions from the testes, duct system and accessory glands that serves as a vehicle for the ejaculated spermatozoa. The biochemical components of bull seminal plasma, such as free amino acids, reducing sugars and proteins, are crucial for spermatozoa survival and function, although

Recebido para publicação em 28 de junho de 2003

Recebido para publicação, após modificações, em 25 de outubro de 2004

E-mail: teresinha@unb.br 
their exact roles in fertility are not fully understood.

Few scientific articles have reported investigations on the effect of seminal plasma constituents, mostly proteins, on fertility. For instance, Killian et al. (1993), using twodimensional gel electrophoresis technology, correlated bull fertility to the levels of four seminal plasma proteins, two of them more prominent in higher fertility individuals and the other two more abundant in the lower fertility ones.

The sugar composition of the seminal plasma has been related with fertility, due to its importance, mainly for spermatozoa energy production (Willians and Ford, 2001). Fructose, that is the main sugar of the seminal plasma, is originated from the seminal vesicles and is essential for the spermatic metabolism and motility (Lewis-Jones et al., 1996).

The function of seminal plasma free amino acids is not totally established although they were shown to act as fuels for the spermatozoa, to create favorable conditions for cell survival and to be probably involved in detoxifying functions (Al-Hakim et al., 1974; Ibrahim and Boldizsár, 1981). They are produced in the testes, epididymis and sex acessory glands and also by action of endogenous proteolytic enzymes on seminal proteins after ejaculation (Roussel and Stallcup, 1967). No direct relationship between seminal plasma free amino acids and fertility has been observed, except for glutamic acid that, together with aspartic acid, serine, alanine and glycine, constitute the largest portion of free amino acids in this fluid (Roussel and Stallcup, 1967).

The present study aimed at evaluating the correlation between fertility and the biochemical composition of Nelore bulls (Bos taurus indicus) seminal plasma samples in terms of protein, reducing sugar and free amino acid concentrations.

\section{MATERIALS AND METHODS}

Semen samples were collected from 19 adult Nelore bulls (Bos taurus indicus) of the same genetic line (Lemgruber) used in the breeding program of Mundo Novo farm (Brotas, SP, Brazil). The semen samples were collected using electroejaculation and were analyzed physically and morphologically, according to the rules of the Colégio Brasileiro de Reprodução Animal (Fonseca et al., 1992). Following collection, sperm samples were examined visually for motility using a light microscope. Two hundred cells from each ejaculate were examined and visually identified as having normal or abnormal structure using a phase contrast microscope. Sperm cell concentration was determined using a Neubauer chamber. The samples were maintained in ice until they were centrifuged at $1500 \mathrm{~g}$ for $15 \mathrm{~min}$ at $4^{\circ} \mathrm{C}$ in order to isolate the seminal plasma. The seminal plasma samples were aliquoted and conserved at $-20^{\circ} \mathrm{C}$ prior to biochemical analyses.

The Nelore cows used were all multiparous and under 10 years of age, had good body condition scores, displayed regular estrus cycles and had calved the year before the trial. The animals were submitted to natural breeding or artificial insemination during a breeding season of 90 days. The cows were checked for pregnancy 60 days after the breeding season.

The protein content of the seminal plasma was determined by a modification of the Bradford's method (Redinbaugh and Campbell, 1985) using bovine serum albumin as standard. The concentration of seminal plasma reducing sugars was determined by the 3,5-dinitrosalycilic acid (DNS) method (Miller, 1959) using fructose as standard. For determination of the seminal plasma free amino acid composition, the samples were initially precipitated with three volumes of cold acetone and incubated for $2 \mathrm{~h}$ at $-20^{\circ} \mathrm{C}$. After centrifugation, the supernatant was removed and freeze dried ${ }^{1}$. The precipitated samples were diluted in $\mathrm{HCl} 0.1 \mathrm{M}$ and applied to an amino acid analyzer ${ }^{2}$ using post column derivatization with ninhydrin (Ozols, 1990).

The estimated fertility of the bulls was based on pregnancy results of 2743 matings from which 1757 resulted in confirmed pregnancy (64\%). These matings occurred in three subsequent breeding seasons either by natural breeding or artificial insemination. A total of 30 bulls were

\footnotetext{
${ }^{1}$ Speed Vac SC 100, Savant Instruments Inc., NY, USA

${ }^{2}$ Hitachi L-8500, Tokyo, Japan
} 
used in these matings from which the 19 with the highest amount of information had semen samples collected for the analyses, such that the number of cows mated to each of these bulls was always above 60 .

Due to the unbalanced structure of the data and the discrete nature of the observations they were analyzed according to a generalized mixed linear model (Cox and Snell, 1996). The model assumed an underlying scale of the predisposition to pregnancy according to the following model:

$y_{i j k}=M_{i}+a_{j}+b_{k}$, where:

$y_{i j k}=$ predisposition to pregnancy of a cow mated to the bull $\mathrm{k}$, in the year $\mathrm{j}$ by the method $\mathrm{i}$; $M_{i}=$ mean of the predisposition to pregnancy by the method i (1 - natural breeding, 2- artificial insemination)

$a_{j}=$ random effect of the year $\mathrm{j}$ on the predisposition of pregnancy of the cows, $a_{j} \sim$ iid $N\left(0, \sigma_{a}^{2}\right)$;

$b_{k}=$ random effect of the bull $\mathrm{k}$ on the predisposition to pregnancy of the cows mated to it, $b_{k} \sim$ iid $N\left(0, \sigma_{b}^{2}\right)$.

According to the predisposition to pregnancy that the cow was subjected to, it either get pregnancy or not, according to a probability defined by a probit link function, that is

$P_{i j k}=\Phi\left(y_{i j k}\right)$, where:

$P_{i j k}=$ probability of pregnancy of the cow mated to the bull $\mathrm{k}$ in the year $\mathrm{j}$ by the method $\mathrm{i}$;

$\Phi\left(y_{i j k}\right)=$ cumulative distribution function of the standard normal for the value of the predisposition to pregnancy of the cow mated to the bull $\mathrm{k}$, in the year $\mathrm{j}$ by the method $\mathrm{k}$.

In order to estimate the bull fertility a Bayesian estimation procedure based on a Gibbs sampling chain of 15,000 samples were performed. The variance components for the effects of year and bull were assumed to have a flat prior information. The overall fertility of the bulls was given by the posterior mean of the probability of pregnancy of a cow mated to that bull in a breeding scheme that resulted in $70 \%$ pregnancy rate.

The correlation coefficients (r) between fertility and the levels of each seminal plasma component were calculated using Microsoft Excel TM software.

\section{RESULTS}

The 19 Nelore bulls used were subjected to a breeding soundness test and relative values of sperm motility ranged from 60 to $90 \%$ and the intensity of spermatic movement (scale of 1-5) was between 3 and 5 . The spermatozoa concentration of the semen varied from 75 to 1320 million (cells $/ \mathrm{ml})$. The percentage of cells presenting abnormalities ranged from 3 to $9 \%$ only, confirming the good quality of the semen produced by the bulls.

Despite the fact that all bulls were classified as excellent in the breeding soundness exam, it was found a posterior mean of $0.0949 \pm 0.0361$ for the variance component of bull in the underlying scale. A histogram of the samples with the probability mass concentrated away from zero enforces the idea that there were fertility differences among the bulls (Fig. 1). This, in turn, resulted in differences in the estimates of bull fertility ranging from $53.2 \%$ to $83.7 \%$ among the 19 bulls who had their semen sampled for further testing. This difference is very important in practice and implies that there is more to be determined about bull fertility than what is currently accessed by the breeding soundness exam. The estimated fertilities of the bulls are presented in Table. 1. 


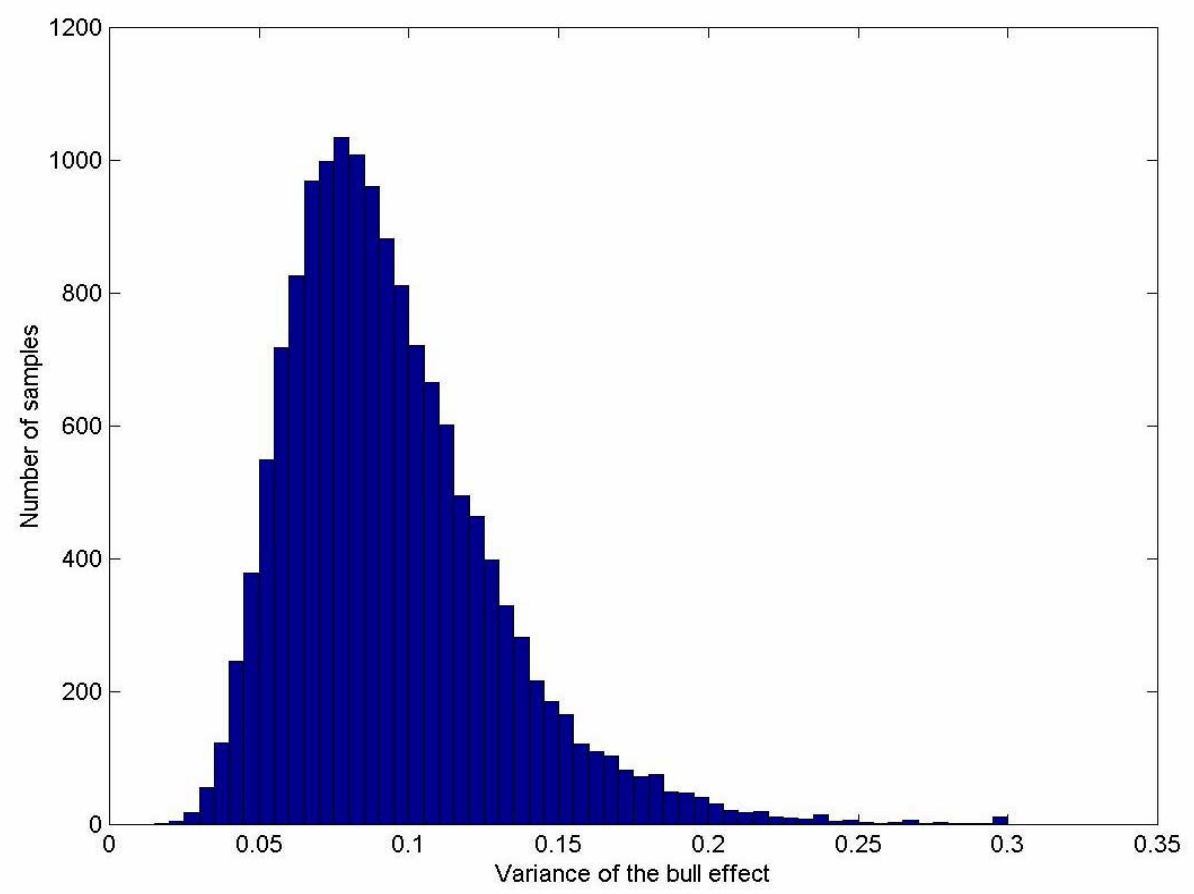

Figure 1. Histogram of 15,000 samples from the posterior distribution of the variance component for the effect of Nelore bulls on the pregnancy rate of the cows they were mated to.

Table 1. Concentrations of protein, reducing sugar and free amino acids (free AA), in seminal plasma of Nelore bulls with different fertility scores

\begin{tabular}{lccc}
\hline $\begin{array}{l}\text { Fertility } \\
(\%)\end{array}$ & $\begin{array}{c}\text { Protein } \\
(\mathrm{mg} / \mathrm{ml})\end{array}$ & $\begin{array}{c}\text { Sugars } \\
(\mathrm{mg} / \mathrm{ml})\end{array}$ & $\begin{array}{c}\text { Free AA } \\
(\mu \text { moles } / \mathrm{ml})\end{array}$ \\
\hline 53.2 & 12.94 & 2.69 & 2.54 \\
57.1 & 9.23 & 1.67 & 0.72 \\
63.9 & 20.35 & 5.04 & 2.64 \\
64.5 & 15.65 & 5.82 & 1.37 \\
68.3 & 4.74 & 1.16 & 2.63 \\
69.0 & 20.73 & 8.12 & 1.36 \\
71.8 & 17.90 & 6.81 & 3.08 \\
72.5 & 11.20 & 2.29 & 1.55 \\
72.8 & 12.44 & 3.40 & 3.54 \\
73.8 & 11.30 & 2.22 & 2.52 \\
74.5 & 21.70 & 4.63 & 3.52 \\
75.1 & 11.19 & 3.20 & 3.08 \\
75.2 & 27.00 & 8.22 & 1.10 \\
76.7 & 1.51 & 0.69 & 1.44 \\
79.4 & 1.65 & 0.61 & 1.37 \\
80.0 & 33.00 & 7.39 & 1.54 \\
81.9 & 7.80 & 1.40 & 2.33 \\
83.0 & 3.78 & 1.06 & 1.55 \\
83.7 & 13.50 & 3.34 & 2.37 \\
\hline
\end{tabular}

The protein assays showed a large variation in the protein concentration among the samples of the seminal plasma. The average amount of protein in the seminal plasma of the 19 animals was of $13.5 \mathrm{mg} / \mathrm{ml}$. The content of reducing sugars and free amino acids in the seminal plasma was also variable with average concentrations of $3.67 \mathrm{mg} / \mathrm{ml}$ and $2.12 \mu \mathrm{mol} / \mathrm{ml}$, respectively.

The concentration of 17 types of free amino acids was determined for all seminal plasma samples and the same types of amino acids were detected. The amino acids that presented the highest concentrations in $\mu \mathrm{mol} / \mathrm{ml}$ were glutamic acid $(0.52 \pm 0.35)$, glycine $(0.38 \pm 0.35)$ and alanine $(0.26 \pm 0.12)$, while methionine $(0.02 \pm 0.01)$, arginine $(0.03 \pm 0.02)$ and tyrosine $(0.03 \pm 0.01)$ showed the smallest amounts.

The $r$ values between bull fertility and the concentration of the biochemical compounds analysed are shown in Table 2. A high 
correlation coefficient $(r=0.90)$ between protein and reducing sugars concentrations was found. The correlation coefficient values between protein and free amino acid as well as reducing sugars and free amino acid concentrations were not statistically significant.

Table 2. Correlation between fertility and biochemical compounds of Nelore bull seminal plasma

\begin{tabular}{lc} 
plasma & Fertility \\
\hline Proteins & -0.07 \\
Free amino acids & 0.04 \\
Reducing sugars & -0.08 \\
Methionine & 0.11 \\
Arginine & -0.02 \\
Tyrosine & -0.26 \\
Cysteine & 0.14 \\
Phenilalanine & 0.01 \\
Isoleucine & 0.13 \\
Histidine & -0.24 \\
Lysine & -0.19 \\
Valine & 0.26 \\
Threonine & 0.08 \\
Proline & 0.08 \\
Aspartic acid & -0.15 \\
Serine & -0.04 \\
Leucine & -0.09 \\
Alanine & 0.1 \\
Glycine & 0.21 \\
Glutamic acid & -0.09 \\
\hline
\end{tabular}

\section{DISCUSSION}

In general, it was observed that the biochemical composition of the Nelore semen samples presented large variability. For instance, the protein concentration of the 19 samples ranged from 1.51 to $33 \mathrm{mg} / \mathrm{ml}$ with an average value of $13.5 \mathrm{mg} / \mathrm{ml}$. Roncoletta (1999) has previously reported a protein concentration in Nelore bull seminal plasma, ranging from 33 to $111 \mathrm{mg} / \mathrm{ml}$ with an average concentration of $61.74 \mathrm{mg} / \mathrm{ml}$. These values were much higher than that observed in the present study, perhaps due to the higher genetic variability of the animals used in their research. No significant correlation between the protein concentration in the seminal plasma and estimated bull fertility was found.

Fructose and glucose represent the main sugars in the seminal plasma and they are essential for ATP production and motility of the spermatozoa (Inskeep et al., 1985; Williams and Ford, 2001).
A high variability in reducing sugar concentration among the seminal plasma samples $(0.61$ to $8.22 \mathrm{mg} / \mathrm{ml})$ was observed. These values were similar to those published by Georgiev et al. (1985) that reported average fructose levels in the seminal plasma of $2.49 \pm 0.12 \mathrm{mg} / \mathrm{ml}$ in mature bulls, and by Killian and Amann (1974) who found values of $4.5 \mathrm{mg} / \mathrm{ml}$. Inskeep et al. (1985) working with bulls and Martikainen et al. (1980) and Willian and Ford (2001) with human seminal plasma investigated the importance of glucose in ATP production, spermatic capacitation and acrosomic reaction. No correlation between sugar levels and estimated bull fertility was found, but a high correlation between sugar and protein levels was observed $(\mathrm{r}=0.90)$. Montagnon et al. (1990) obtained similar results in human seminal plasma. The correlation is probably due to the common origin of reducing sugars and proteins in the accessory sex glands.

The 17 free amino acids analyzed were also studied by Roussel and Stallcup (1967) and Sexton et al. (1971) in Holstein animals, while Al-Hakim et al. (1970) found 20 free amino acids. Smith and Graham (1972) also found the same 17 amino acids in the seminal plasma of rams and Hernvan et al. (1986) detected 19 amino acids in the seminal plasma of men. The free amino acid with the highest concentrations in all samples was the glutamic acid, followed by glycine and alanine, comprising $60.5 \%$ of the total. Similar results were reported by Roussel and Stallcup (1967), Al-Hakim et al. (1970) and Sexton et al. (1971) in bovines and by Smith and Graham (1972) in sheep. All of them observed that the glutamic acid was the most abundant amino acid in the seminal plasma. For the glutamic acid of seminal plasma the average concentration was $0.52 \pm 0.35 \mu \mathrm{mol} / \mathrm{ml}$. Al-Hakim et al. (1970) obtained $4.35 \mu \mathrm{moles} / \mathrm{ml}$ and Sexton et al. (1971) found $4.54 \mu \mathrm{moles} / \mathrm{ml}$. No correlations between the levels of the 17 types of free amino acid measured in the seminal plasma and the fertility of the bulls were observed (Table 2). Oltjen et al. (1971) and Roussel and Stallcup (1967) did not find such correlation either, but showed that high amounts of total free amino acids are important for the semen quality and the fertility of the animal. Al-Hakim et al. (1970) verified a linear correlation between glutamic and aspartic acids and fertility of Holstein bulls. Ibrahim and Boldizsár (1981) classified a population of bulls in two groups according to 
their total amino acid concentrations and found that the average fertility score of the group containing elevated free amino acid concentration was slightly higher than the group of low amino acid levels. Using the same approach, however, similar behavior for Nelore bulls was not found in this study.

It was evidenced that the composition of the seminal plasma in terms of protein, reducing sugars, and free amino acids concentrations showed a high individual variability in Nelore bulls. None of the molecules analyzed here showed a significant correlation with fertility. However it was found a significant correlation between levels of proteins and reducing sugars. Overall, the results do not indicate that any of the components of the seminal plasma, by itself, can explain bull fertility. These findings reinforce the idea that the fertility of bulls depends on a complex set of components that act in concert.

\section{ACKNOWLEDGEMENTS}

Authors thank to Mundo Novo Farm (MANAH S.A.) for the concession of animals used in the experiments. We also thank N. M. Domingues and L. X. Cardoso for technical assistance during the amino acid analysis.

\section{REFERENCES}

AL-HAKIM, M.K.; GRAHAM, E.F.; SCHMEHL, M.L. Free amino acids and amino compounds in bovine seminal plasma. J. Dairy Sci., v.53, p.84-88, 1970.

AUSTIN, C.R.; SHORT, R.V. Reproduction in mammals - Germ cells and fertilization. New York: Cambridge University, 1990. 285p.

COX, D.R.; SNELL, E.J. Analysis of binary data. New York : Chapman \& Hall, 1996.

FONSECA, V.O.; VALE FILHO, V.R.; MIES FILHO, A. et al. Procedimentos para exame andrológico e avaliação de sêmen animal. Belo Horizonte: Colégio Brasileiro de Reprodução Animal, 1992. 79p.

GEORGIEV, G.; IOSIFOV, K.; TSEKOVA, E. Fructose and the fructolysis index in bull semen. Vet. Med. Nauki., v.12, p.27-31, 1975.
HERNVANN, A.; GONZALES, J.; TROUPEL, S. et al. Amino acids content of human in normal and infertility cases. Andrologia, v.18, p.461469, 1986.

IBGE : 2003 - Instituto Brasileiro de Geografia e Estatística, http://www.ibge.gov.br

IBRAHIM, M.A.R.; BOLDIZSÁR, H. Studies on free amino acid content in seminal plasma of I. A. bulls of diferent performance. Acta Vet. Acad. Sci. Hung., v.29, p. 263-269, 1981.

INSKEEP, P.B.; MAGARGEE, S.F.; HAMMERSTEDT, R.H. Alterations in motility and metabolism associated with sperm interaction with accessory sex gland fluids. Arch. Bioch. Bioph., v.241, p.1-9, 1985.

KILLIAN, G.J.; AMANN, R.P. Reproductive capacity of dairy bulls. X. Changes in chemical components and immunoelectrophoretic characteristics of seminal plasma before and after puberty. J. Dairy Sci., v.57, p.703-706, 1974.

KILLIAN， G.J.; CHAPMAN， D.A.; ROGOWSKI, L.A. Fertility-associated proteins in Holstein bull seminal plasma. Biol. Reprod., v.49, p.1202-1207, 1993.

LEWIS-JONES, D.I.; AIRD, I.A.; BILJAN, M.M. et al. Effects of sperm activty on zinc and fructose concentrations in seminal plasma. Human Reprod., v.11, p.2465-2467, 1996.

MARTIKAINEN, P.; SANNIKKA, E.; SUOMINEN, J. et al. Glucose content as a parameter of semen quality. Arch. Androl., v.5, p.337-343, 1980.

MILLER, G.L. Use of dinitrosalicylic acid reagent for the determination of reducing sugar. Anal. Chem., v.31, p.426-428, 1959.

MONTAGNON, D.; VALTAT, B.; VIGNON, F. et al. Secretory proteins of human seminal vesicles and their relationship to lipids and sugars. Andrologia, v.22, p.193-204, 1990.

OLTJEN, R.R.; BOND, J.; GERRITS, R.J. et al. Growth and reproductive performance of bulls and heifers fed purified and natural diets. V. Free amino acid in the semen and blood plasma of bulls (puberty to 148 weeks of age). J. Anim. Sci., v.33, p.814-818, 1971.

OZOLS, J. Amino acid analysis. In: DEUTSCHER, M. P. (Ed.), Methods in 
Enzymology - Guide to protein purification. New York: Academic, 1990. V.182, p.587-601.

REDINBAUGH, M.G.; CAMPBELL, W.H. Adaptation of the dye-binding protein assay to microtitre plates. Anal. Biochem., v.147, p.144147, 1985.

RONCOLETTA, M. Perfil em SDS-page das proteinas de espermatozóide e plasma seminal relacionados com a congelabilidade do semen. 1999. 109f. Tese (Mestrado) - Faculdade de Ciências Agrárias e Veterinárias, UNESP, Jaboticabal, SP.
ROUSSEL, J.D.; STALLCUP, O.T. Some amino acids aspects of bovine semen. Fertil. Steril. , v.18, p.331-341, 1967.

SEXTON, T.J.; AMANN, R.P.; FLIPSE, R.J. Free amino acids and protein in rete testis fluid, vas deferens plasma, accessory sex gland fluid and seminal plasma of conscious bull. J. Dairy Sci., v.54, p.412-413, 1971.

SMITH, J.D.; GRAHAM, E.F. Free amino acids in ram seminal plasma. J. Anim. Sci., v.34, p.601-604, 1972.

WILLIAMS, A.C.; FORD, W.C. The role of glucose in supporting motility and capacitation in human. J. Androl., v.22, p.680-695, 2001. 